\title{
Study of Genetic Variability, Heritability and Genetic Advance in Cowpea [Vigna unguiculata (L.) Walp]
}

\author{
Jogdhande Srinivas $^{1}{ }^{*}$, Vijay S. Kale ${ }^{1}$ and P.K. Nagre \\ ${ }^{1}$ Department of Horticulture, Dr. PDKV, Akola, Maharashtra, India \\ *Corresponding author
}

\section{A B S T R A C T}

\begin{tabular}{|l|}
\hline Ke y w o r d s \\
Cowpea, Genetic \\
variability, \\
Heritability, \\
Genetic advance. \\
\hline Article Info \\
\hline $\begin{array}{l}\text { Accepted: } \\
15 \text { May } 2017 \\
\text { Available Online: } \\
\text { 10 June } 2017\end{array}$ \\
\hline
\end{tabular}

\begin{abstract}
Studies on genetic variability, heritability and genetic advance were carried out with thirty genotype of cowpea [Vigna unguiculata (L.) Walp] for 16 traits. Significant differences among the genotypes for all the characters indicating existence of ample variability in the experimental material for all the characters. High to moderate range of variation was observed for important yield components. The estimate of genotypic and phenotypic coefficient of variation were high for number of branches per plant, pod yield per plot $(\mathrm{kg})$, total number of pods per plant, number of seeds per pod. The values of phenotypic coefficient of variation were higher than their genotypic co-efficients of variation for all the characters indicating the influence of environmental factors. High heritability along with high genotypic co-efficient of variation was observed for number of branches per plant, pod yield per plot $(\mathrm{kg})$, total number of pods per plant, number of seeds per pod indicating scope for improvement by selection and breeding programme.
\end{abstract}

\section{Introduction}

Cowpea [Vigna unguiculata (L.) Walp] is an important leguminous vegetable crop mainly grown both in kharif and spring summer season crop in most parts of India. It is native to West Africa Vavilov (1951), but Steele (1976) suggested Ethiopia as the primary and Africa as the secondary centres of diversity. The total area of beans in India is 37.54 million hectares with production of 1370.21 million tonnes (Anon., 2014).

Cowpea [Vigna unguiculata (L) Walp] is an important multi-purpose grain legume extensively cultivated in arid and semi- arid regions of the world as pulse, vegetable, fodder as well as green manure crops. Being short duration and photo- insensitive, it can be grown successfully throughout the year, in all types of soils and varying climatic conditions cowpea is a protein rich crop, demands more attention especially in a country like India, where majority of the vegetarians suffer for protein malnutrition. It contains 24 per cent protein, 60 per cent carbohydrate and 2 per cent fat besides being good sources of vitamins and phosphorus.

The market demand also changing and there are ample opportunities for cowpea to develop into a most popular vegetable crop made available throughout the year. The genetic variability study helpful to estimated 
by suitable parameter of variation as heritability estimates and expected genetic advance for the individual characters, variability is therefore the key factors, which determine the amount of progress expected from selection. The correlation studies between yield and its component characters have been immense help in selecting suitable plant type. The need for studying the magnitude of interrelationship between different characters is important in many cases.

Hence it is very necessary to estimate genotypic correlation coefficients for designing to reliable and efficient breeding programme. The knowledge of association among component of economically importance and other traits can helps in improving the efficiency of selection by making possible use of suitable combination of characters in an improvement programme.

\section{Materials and Methods}

The present investigation "Study of genetic variability, heritability and genetic advance in cowpea [Vigna unguiculata (L.) Walp] was carried out at Main Garden, University Department of Horticulture, Dr. Panjabrao Deshmukh Krishi Vidyapeeth, Akola, during summer season of the year 2014-2015. The study was under taken on 30 genotypes of cowpea using randomized block design with three replication. Keeping a plot size of $3.5 \mathrm{~m}$ $\mathrm{x} 1.16 \mathrm{~m}$.

The plot was selected on the basis of suitability of the land for cultivation of cowpea. Analysis of variance was calculated as per method suggested by Panse and Sukhatame (1985). The phenotypic and genotypic coefficient of variation (PCV, GCV) was estimated as per Burton (1952). Heritability in a broad sense and genetic advance were computed according to Johnson et al., (1955.)

\section{Source of plant materials}

The 30 genotypes of cowpea different region CL-14, CL-10, Arka suman, CL-8, CL-3, CL8, Divya, CL-24, Gomati, Vanita, Konkan Sadabahar, Gayatri, AKCP-20 (VN) Green selection, CL-13,C L-12, Selection-5, CL-5, Gadchiroli local -2, CL-23, Pusa komal, Kashi Kanchan, AKCP- 31 (SAR), AKCP-99 (SAR), Gadchiroli local (RS)-3, Akola selection, Baramasi, AKCR -14 (Red), Arka samrudhi, CL-17, AKCP-f-7. The data was recorded on following quantitative parameters plant height, first flower $50 \%$ flowering, Number cluster per plant, Number of Green pods for cluster, Number pods per plant, Pod length, Pod yield per hectare(q), Percentage of protein content.

\section{Results and Discussion}

The analysis of variance indicate highly significant different among thirty genotypes for all the sixteen characters under study. This indicates that the genotypic which were used for study have sufficient amount of variation for all the characters and hence selection will be very effective. Maximum range of mean values was observed for days to $50 \%$ flowering followed by days to required first flower and total number of pods per cluster. The minimum range of mean values was recorded for plant height. In general the phenotypic coefficient of variation was higher than the genotypic coefficient of variation for all the characters (Table 1). Wide range of coefficient of variations were observed for number of branches per plant, plant height, pod yield per plot $(\mathrm{kg})$, total number of pods per cluster, number of seeds per pod, number of nodes on main branch, pod length $(\mathrm{cm})$ and 100 seed weight at phenotypic and genotypic level respectively, indicating high level of variability in these character and ample scope for effective improvement. High estimate of phenotypic variability alone will not be 
enough to determine exact nature of variability. Genotypic coefficient of variation would be more useful for assessing the variability (Allard, 1970).

High phenotypic co-efficient of variation (PCV) was observed for number of branches per plant, plant height, pod yield per plot $(\mathrm{kg})$, total number of pod per plant, number of seeds per pod. Similar results were recorded by Selvam et al., (2000) for total number of pod per plant, Venkatesan et al., (2003) for 100 seed weight, Vardhan and Savithramma (1998) for green pod yield per plant, Nigude et al., (2004) for plant height. Certain characters like pod length, number of green pods per cluster, 100 seed weight, number of green pods per cluster exhibited moderate values of this estimate. Nigude et al (2004) also reported the moderate PCV for pod length and number of green pods per cluster.

High genotype co-efficient of variation (GCV) was observed for number of branches per plant, plant height, pod yield per plot $(\mathrm{kg})$, total number of pod per plant, number of seeds per pod. High GCV thereby suggesting that these characters could be improved genetically. Similar magnitude of these parameters were also found by $\mathrm{Pal}$ et al., (2003) for plant height, pod, pod yield per plot $(\mathrm{kg})$, total number of pod per plant, Venkatesan et al., (2003) for 100 seed weight.

The co-efficient of variation does not offer full scope to estimate the heritable variation. The relative amount of heritable portion of variation is assessed with the help of heritable estimates and genetic advance expressed as percentage of the mean (genetic gain). The success of selection depends on the breeding value of a genotype recognized from its phenotypic expression. The degree of correspondence between phenotypic value and breeding value for a character is measured by heritability, which indicates reliability of the formers as a guide to the later. The heritability expresses the proportion of total variance that is attributed to the average effect of gene and determines the degree of resemblance between relatives. It is a good index of transmission of characters from parents to their off-springs (Falconer, 1981). High values of heritability in broad sense are helpful in identifying the appropriate character for selection and enabling the breeder to select superior genotypes on the basis of phenotypic expression of quantitative traits (Johnson et al., 1955).

Moderate to high estimate ( $>63 \%$ ) of broadsense heritability were noticed for all the character under studies. These results are in agreement with those of Nigude et al., (2004); Venkatesan et al., (2003) and Pan et al.,(2004).High heritability estimates indicated that the characters were least influenced by the environmental effects. This also suggested that the phenotypes were the true representative of their genotypes of these traits and the selection based on phenotypic value could be reliable. In a crop improvement programme the highly heritable characters may be selected early in the programme and selection of characters with low heritable may be postponed till they are close to complete homozygosis (Sakai, 1951). Characters showing high heritability values indicate that they have more number of additive factors (Panse, 1957).

High values of genetic advance expressed as percent of mean were exhibited by number of branches per plant (70.175), plant height $(\mathrm{cm})$ (58.952), pod yield per plot (kg) (47.956), total number of pods per plant (44.418) and number of seeds per pod (41.398) (Table 1).High/ moderate estimates of these parameters were also reported by Nigude et al., (2004), Narayankutty et al., (2003) and Pal et al., (2003). Whereas the remaining characters manifested moderate to low genetic advanced as percentage of mean. 
Table.1 Estimates of variability, heritability, expected genetic advances per cent of mean

\begin{tabular}{|c|c|c|c|c|c|c|c|c|}
\hline $\begin{array}{l}\text { Sr. } \\
\text { No. }\end{array}$ & Character & Range & Mean & $\begin{array}{l}\text { PCV } \\
(\%)\end{array}$ & $\begin{array}{c}\text { GCV } \\
(\%)\end{array}$ & $\begin{array}{r}\text { ECV } \\
(\%)\end{array}$ & $\begin{array}{l}\text { Heritability } \\
\left(\mathbf{h}^{2}\right) \%\end{array}$ & $\begin{array}{l}\text { Expected genetic } \\
\text { advance as \% over } \\
\text { mean }\end{array}$ \\
\hline 1. & Plant height $(\mathrm{cm})$ & $26.33-70.40$ & 37.5058 & 28.928 & 28.772 & 2.996 & 0.989 & 58.952 \\
\hline 2. & Number of branches per plant & $9.40-25.98$ & 17.3561 & 34.615 & 34.339 & 4.359 & 0.984 & 70.175 \\
\hline 3. & Number of nodes on main branch & $10.73-24.40$ & 16.5889 & 19.596 & 18.665 & 5.971 & 0.907 & 36.621 \\
\hline 4. & Days require to first flower & $40.80-66.20$ & 53.6370 & 16.710 & 16.635 & 1.578 & 0.991 & 34.116 \\
\hline 5. & Days to $50 \%$ flowering & $44.80-75.40$ & 58.1907 & 15.514 & 15.401 & 1.870 & 0.985 & 31.494 \\
\hline 6. & Number of cluster per plant & $14.0-22.3$ & 18.1111 & 14.460 & 14.353 & 1.759 & 0.985 & 29.348 \\
\hline 7. & Number of green pods per cluster & $2.40-3.53$ & 2.8356 & 10.243 & 9.684 & 3.336 & 0.894 & 18.861 \\
\hline 8. & Total number of pods per plant & $38.70-87.80$ & 52.0711 & 22.314 & 21.935 & 4.097 & 0.966 & 44.418 \\
\hline 9. & Pod length $(\mathrm{cm})$ & $11.93-25.60$ & 20.5111 & 17.750 & 17.661 & 1.783 & 0.990 & 36.197 \\
\hline 10. & Pod diameter $(\mathrm{cm})$ & $0.599-0.807$ & 0.6894 & 7.724 & 7.419 & 2.147 & 0.923 & 14.682 \\
\hline 11. & 100 seed weight & $7.67-17.87$ & 11.5534 & 14.197 & 14.077 & 1.843 & 0.983 & 28.754 \\
\hline 12. & Number of seeds per pod & $7.67-16.33$ & 12.8200 & 20.201 & 20.148 & 1.452 & 0.995 & 41.398 \\
\hline 13. & Average pod weight (g) & $4.03-8.55$ & 5.2258 & 12.271 & 9.395 & 7.893 & 0.586 & 14.819 \\
\hline 14. & Pod yield per plot (kg) & $2.459-5.274$ & 4.0806 & 24.731 & 23.994 & 5.991 & 0.941 & 47.956 \\
\hline 15 & Percentage of fiber content & $1.09-2.01$ & 1.6754 & 13.436 & 13.134 & 2.832 & 0.956 & 26.447 \\
\hline 16 & Percentage of protein content & $15.88-23.80$ & 19.9774 & 10.548 & 10.316 & 2.201 & 0.956 & 20.783 \\
\hline
\end{tabular}


The high heritability due to favourable influence of environment world not contribute much through selection. As such, progeny or family testing is to be practiced for amelioration of these traits. However, they can be improved by developing of hybrid varieties or utilization of transgressive segregants in heterosis breeding programme. High heritability along with genetic advance was recorded in number of branches per plant, plant height $(\mathrm{cm})$, pod yield per plot $(\mathrm{kg})$, total number of pod per plant, number of seeds per pod. These characters also recorded high value of genotypic and phenotypic coefficient of variation which indicated that these characters could be considered for improvement through individual plant selection. The above results are in agreement with the finding of Hazra et al., (1999) who reported high values of phenotypic and genotypic coefficient of variation, heritability and genetic advance for the traits.

\section{References}

Allard, R.W. 1970. Principles of plant breeding. John willey and son. Inc; New York. pp. 485.

Anonymous. 2014. Area and production of vegetable crops in India. Indian Horticulture Database, National Horticulture Board.

Falconer, D.S. 1981. An introduction to quantitative genetics, Longman, New York, U. S. A.

Hazra, P.A., Chattopadhyay and M.K. Pandit. 1999. Genetic variability in three cultigroups of cowpea. J. Interacdemicia, 3(3/4): 263268.

Narayanankutty, C., R. Mili and U. Jaikumaran. 2003. Variability and genetic divergence in vegetable cowpea. J. Maharashtra Agric.
Univ., 28(1): 26-29.

Nigude, A.D., A.D. Dumbre, D.B. Lad and N. D. Bangar. 2004a. Genetic variability and correlation studies in cowpea. $J$. Maharashtra Agric. Univ., 29(1): 30-33.

Pal, A.K., A.N. Maurya, B. Singh, D. Ram and S. Kumar. 2003. Genetic variability, heritability and genetic advance in cowpea. Vigna unguiculata. L. ) Walp. Orissa $J$. Horticulture, 31(1): 94-97.

Pan, R.S., V.S.R.K. Prasad and M. Rai. 2004. Genetic variability in vegetable cowpea [Vigna unguiculata. L. )Walp]. J. Res. Birsa Agric. Univ., 16(12): 289-292.

Panse, V.G. 1957. Genetics of quantitative traits in relation to plant breeding. Indian J. Genet., 17: 318-328.

Sakai, K. 1951. Studies on individual selection and efficiency in plant breeding. Jap. J. Breed., 1: 1-9.

Selvam, A.Y., N. Manivannan, A.S. Murugan, P. Thangavelu and J. Ganesan. 2000. Variability studies in cowpea. Vigna unguiculata. L.) Walp.) Legume Res., 28(4): 279-280.

Steele, W.M. 1976. Cowpea, Vigna unguiculata. In: Evolution of crop plants,. Eds. R. J. Summerfield and A. H. Bunting, HMSO, London. 183-185.

Vardhan, P.N.H. and D.L. Savithramma. 1998. Variability, character association, path analysis and assessment of quality parameters in cowpea. Vigna unguiculata) germplasm for vegetable traits. ACIAR Food Legume Newslett. No.28: 7-8.

Vavilov, N.I. 1951. The origin, variation, immunity and breeding of cultivated plant. Translated by K. S. Cheaster) Crom. Bot., 13: 364.

Venkatesan, M., M. Prakash and H. Ganesan. 2003. Correlation and path analysis in cowpea. Vigna unguiculata. L.) Walp. Legume Res., 26(2): 105-108.

\section{How to cite this article:}

Jogdhande Srinivas, Vijay S. Kale, and Nagre, P.K. 2017. Study of Genetic Variability, Heritability and Genetic Advance in Cowpea [Vigna unguiculata (L.) Walp]. Int.J.Curr.Microbiol.App.Sci. 6(6): 3314-3318. doi: https://doi.org/10.20546/ijcmas.2017.606.389 